\title{
APT Blanket System Internally Dry Flooded Cavity Accident Based on Initial Plate-Type Design
}

by

L. L. Hamm

Westinghouse Savannah River Company

Savannah River Site

Aiken, South Carolina 29808

S. Y. Lee

M. A. Shadday

F. G. Smith, III

A document prepared for SENDING TO LANL at , , from - .

DOE Contract No. DE-AC09-96SR18500

This paper was prepared in connection with work done under the above contract number with the U.S. Department of Energy. By acceptance of this paper, the publisher and/or recipient acknowledges the U.S. Government's right to retain a nonexclusive, royalty-free license in and to any copyright covering this paper, along with the right to reproduce and to authorize others to reproduce all or part of the copyrighted paper. 


\section{DISCLAIMER}

Portions of this document may be illegible in electronic image products. Images are produced from the best available original document. 
WSRC-TR-98-0064

\section{APT BLANKET SYSTEM INTERNALLY DRY FLOODED CAVITY ACCIDENT (IDFCA) BASED ON INITIAL PLATE-TYPE DESIGN -}

\section{Demonstration of Bin Heat Conduction Capability}

\section{Larry Hamm \\ Si Young Lee \\ M. Andy Shadday \\ Frank G. Smith, III}

Westinghouse Savannah River Company Savannah River Site Aiken, SC 29808

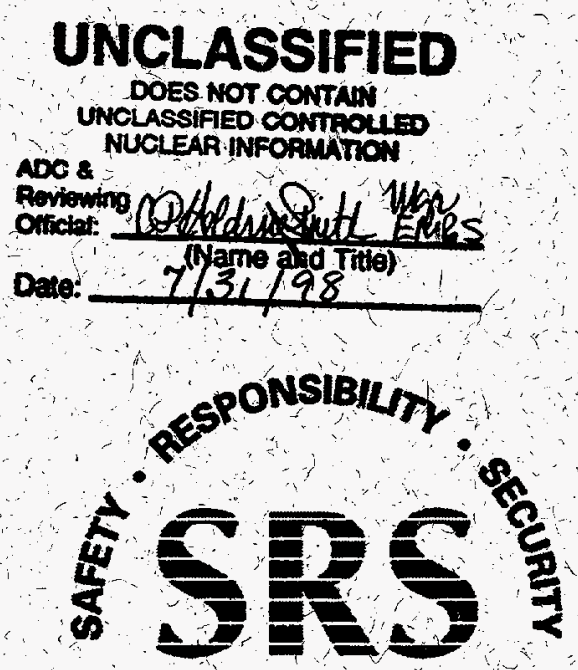




\section{DISCLAIMER}

This report was prepared as an account of work sponsored by an agency of the United States Government. Neither the United States Government nor any agency thereof, nor any of their employees, makes any warranty, express or implied, or assumes any legal liability or responsibility for the accuracy, completeness, or usefulness of any information, apparatus, product, or process disclosed, or represents that its use would not infringe privately owned rights. Reference herein to any specific commercial product, process, or service by trade name, trademark, manufacturer, or otherwise does not necessarily constitute or imply its endorsement, recommendation, or favoring by the United States Government or any agency thereof. The views and opinions of authors expressed herein do not necessarily state or reflect those of the United States Government or any agency thereof.

This report has been reproduced directly from the best available copy.

Available to DOE and DOE contractors from the Office of Scientific and Technical Information, P.O. Box 62, Oak Ridge, TN 37831; prices available from (615) 576-8401.

Available to the public from the National Technical Information Service, U.S. Department of Commerce; 5285 Port Royal Road, Springfield, VA 22161. 
WSRC-TR-98-0064

KEYWORDS:

Accelerator Production of Tritium

Blanket System

Conceptual Design

FLOWTRAN-TF Code

Detailed Bin Model

Safety Analysis

RETENTION - Permanent

\section{APT BLANKET SYSTEM INTERNALLY DRY FLOODED CAVITY ACCIDENT (IDFCA) BASED ON INITIAL PLATE-TYPE DESIGN -}

\section{Demonstration of Bin Heat Conduction Capability}

SAVANNAH RIVER TECHNOLOGY CENTER

L. Larry Hamm

Si Young Lee

$M$. Andy Shadday

Frank G. Smith, III

Publication Date: July 1998

Westinghouse Savannah River Company

Savannah River Site

Aiken, SC 29808

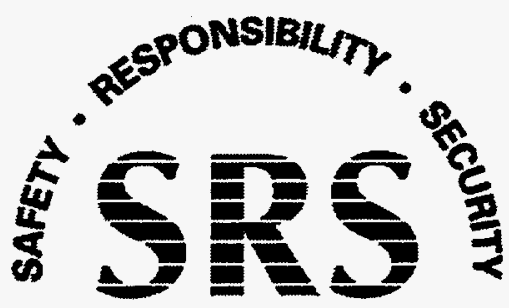

SAYANNAH RIVER SITE

Prepared for the U.S. Department of Energy under Contract No. DE-AC09-96SR18500 
DOCUMENT: WSRC-TR-98-0064

TITLE: APT BLANKET SYSTEM INTERNALLY DRY FLOODED

CAVITY ACCIDENT (IDFCA) BASED ON INITIAL PLATE-

TYPE DESIGN - Demonstration of Bin Heat Conduction

Capability

\section{APPROVALS}

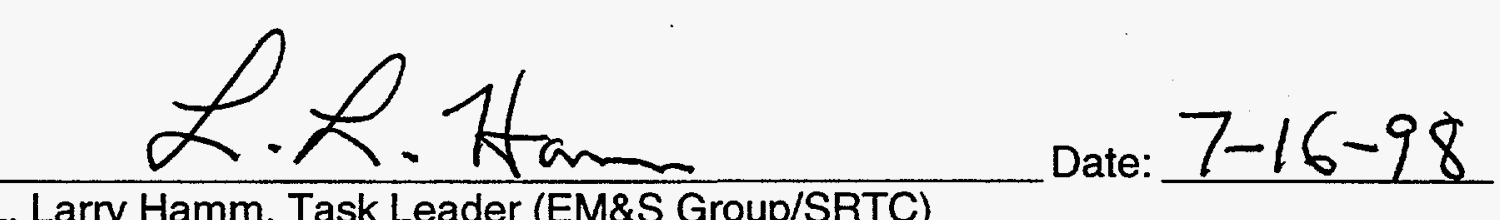

L. Larry Hamm, Task Leader (EM\&S Group/SRTC)

\section{Lary Hamm, Task Leader (EMRS Group/SRTC)}
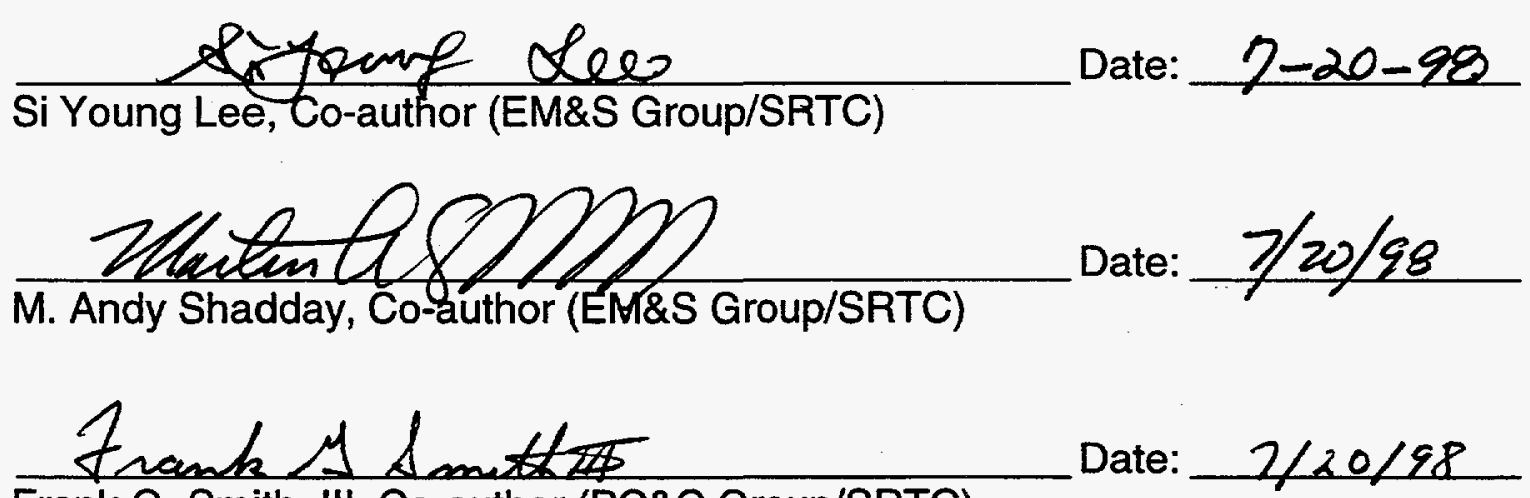

Frank G. Smith, III, Co-author (PC\&C Group/SRTC)

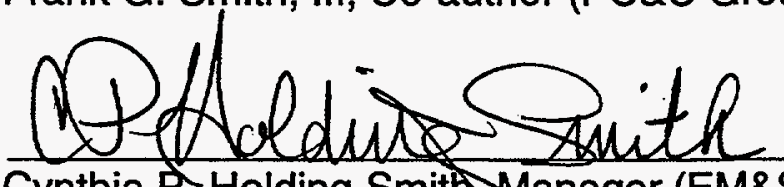

Cynthia P.Holding-Smit (EManager Group/SRTC)

Date: $2 / 20 / 98$

M.Q. ¿fra

Martha A. Ebra, Manager (EDS/SRTC)

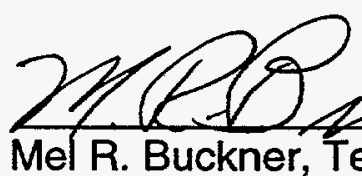

Mel R. Buckner, Technical \& Regulatory Lead (APT OPO)

Date: $7 / 16 / 98$

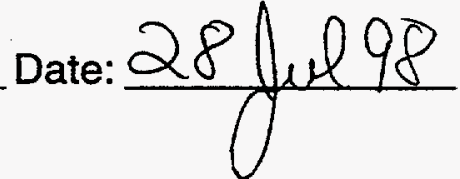

Date:

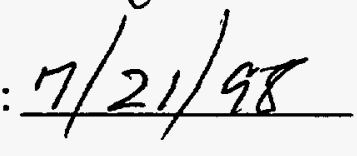

The internal technical review function is being performed at the APT project level and is coordinated through LANL. 


\section{Table of Contents}

1 Introduction ........................................................................................................ 1

2 Background ..................................................................................................... 1

3 Scenario Descriptions .......................................................................................... 4

4 Analysis Results ............................................................................................. 5

5 Decoupler Design Improvement Impact .............................................................13

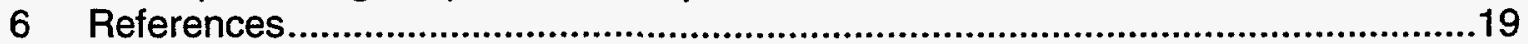

\section{List of Figures}

Figure 2-1 Essential differences between cruciform- and plate-type blanket module components.

Figure 4-1 Maximum aluminum temperature during dry channel accident scenario.

Figure 4-2 Maximum aluminum temperatures for internally dry channel scenario.

Figure 4-3 Plate surface temperatures at 3600 seconds with internally dry flow channels.

Figure 4-4 Cut-away view of plate temperatures at 3600 seconds with internally dry flow channels.

Figure 4-6 Liquid mass in Row 1 Blanket plate cooling channels during boiling............ 9

Figure 4-7 Maximum aluminum temperature in plate during boiling. .............................10

Figure 4-8 Temperature profile at 30 minutes. ..........................................................11

Figure 4-9 Void fraction in flow channel 1 during the boil-down transient.....................12

Figure 4-10 Void fraction in flow channel 8 during the boil-down transient.....................13

Figure 5-1 TRAC component layout for the cavity vessel and cavity flood system.

Figure 5-2 Vertical cross-sectional view of Target/Blanket vessel highlighting the elevation of key cavity vessel components.

Figure 5-3 Timing associated with covering certain key cavity vessel components once a cavity flood actuation has been initiated.

Figure 5-4 Plan view of downstream Row-1 plate-type component highlighting thermal boundary conditions used.

Figure 5-5 Downstream Row-1 plate-type maximum metal temperature response to channel dryout conditions initiated at 100 seconds after beam shutdown. 
(This Page Intentionally Left Blank)

$-i v-$ 


\section{Introduction}

Typically, heat conduction alone is insufficient for cooling components under decay heat conditions. However, due to various design features associated with the blanket modules heat conduction alone can transfer all of the deposited energy when under flooded cavity conditions. A few bounding accident conditions were analyzed to demonstrate this heat conduction capability for the reference 1 plate-type design [8] of a lateral Row- 1 blanket module [8]. These accidents start with a large break internal lossof-coolant initiator and assume that coolant flow and coolant inventory to the blanket modules is lost. Except for supplying initial conditions, system calculations were not required to analyze these accident situations. Rather, the FLOWTRAN-TF code [1-3] was used directly to analyze the postulated bounding accident scenarios.

\section{Background}

At the bin level within a given blanket module, the original design for the solid structures was of a cruciform-type concept as shown in the upper portion of Fig. 2-1. This design consisted of discrete heat structures made of aluminum cladded lead cruciforms placed within a rectangular aluminum structure defined as a local bin. Several bins ganged together constitute an individual blanket module. Within each bin, neighboring cruciform components are spaced apart using discontinuous longitudinal ribs. Within these bins, a continuous coolant channel consists of many sub-channels of varying widths due to fabrication tolerances. This cruciform-type design is based on preliminary normal operation (NO) design calculations only. Later a preliminary safety assessment for the cruciform design was performed [4,5]. The NO calculations in Ref. [6] confirmed the earlier design analyses; however, design concerns emerged for various accident scenarios considered [5]. Reference [5] indicated the need for a new design improvement study. Recognizing (1) that beam shutdown occurs very rapidly, (2) that a significant reduction in decay power occurs, and (3) these lead components are massive and contain large thermal inertia, redesign of the blanket modules at the bin level taking advantage of these features was warranted. The design improvement study centered around:

- taking advantage of the low decay heat conditions (i.e., use heat conduction as a major means for heat removal from the bins);

- eliminating the difficult analysis requirements associated with complex subchanneling due to varying rib geometries.

The expectations for the outcome of this design improvement were more robust blanket modules with much simpler safety analysis requirements, both experimentally and numerically. These expectations were met based on a plate-type design as shown in the lower portion of Fig. 2-1. The main features of the plate-type design is to have a continuous heat structure at the bin level with discrete one-dimensional flow channels dispersed throughout the heat structure. Preliminary safety analyses (both NO and various bounding accident scenarios) were performed to better quantify the thermal/hydraulic benefits over the earlier cruciform design [7]. In this report we extend these preliminary analyses to the reference 1 plate-type design and apply the FLOWTRAN-TF code to obtain a more rigorous calculation. 


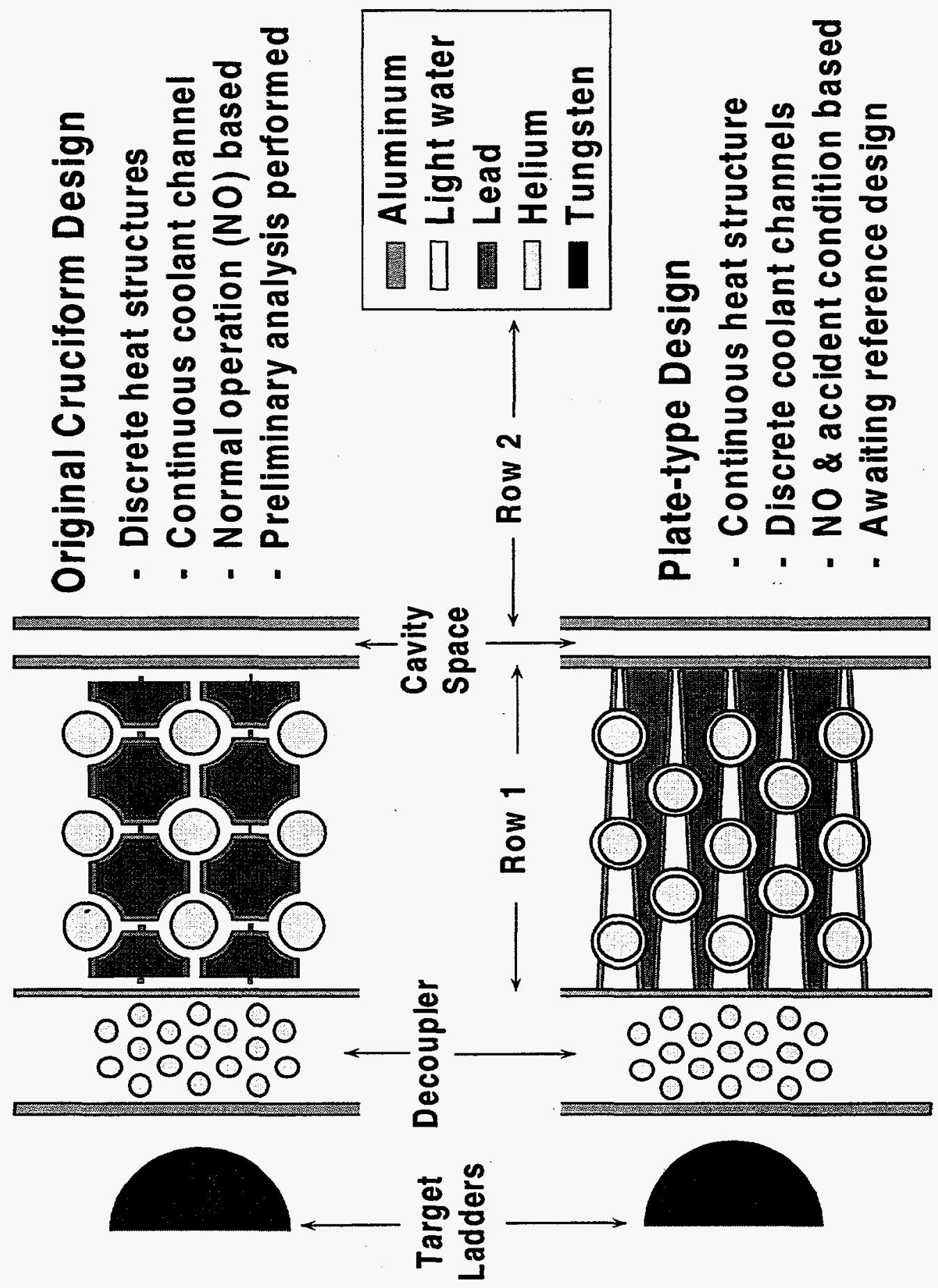

Figure 2-1 Essential differences between cruciform- and plate-type blanket module components. 
The bounding accident scenarios assume that neither residual heat removal system becomes operational, that the cavity flood system successfully floods the vessel, and that various amounts of the coolant inventory within the blanket modules are suddenly lost. To evaluate safety margins in the reference 1 blanket plate design for these extreme accident conditions, several cases where the plate flow channels partially or completely dry out and the accelerator cavity region is flooded with water at $100 \mathrm{C}$ were analyzed. Initially the accelerator is assumed to be operating in a steady-state condition at the nominal design power with the nominal coolant flow and with adiabatic boundary conditions on the cavity and decoupler side surfaces [6]. The postulated accident scenarios then consist of the following components:

1. At time zero, coolant flow begins an exponential decay to the residual-heat-removal system level of $4 \%$ of the pre-incident flow. The coolant flow reaches $4 \%$ at approximately 120 seconds into the transient and remains at this value until 300 seconds. During this period, we assume that the inlet water temperature increases from the pre-incident value of $54.9 \mathrm{C}$ to $85.0 \mathrm{C}$. The $85.0 \mathrm{C}$ temperature is not based on any system analysis but is simply an arbitrary high value. The accelerator beam power is tripped 1 second into the transient and, thereafter, power deposited in the plate follows the power decay curve.

2. At 300 seconds coolant flow begins a second exponential decay to zero flow. The coolant flow reaches zero at approximately 420 seconds and the channels then remain full of water but without flow until 600 seconds. During this period of the transient, we assume that the inlet water temperature increases to $99.5 \mathrm{C}$. At 300 seconds, we also assume that the cavity has flooded with water at $100 \mathrm{C}$. From that time on, we apply an adiabatic boundary condition at the plate surface on the decoupler side and heat transfer to an ambient temperature of $100 \mathrm{C}$ at the plate surface on the cavity side.

3. After building a temperature distribution into the plate metal with steps 1 and 2 , at 600 seconds into the accident scenario, we analyze three separate cases:

3.1 A wet-channel case where water remains in the plate coolant channels and in the upper and lower plenums but does not flow.

3.2 A dry-channel case where the inventory of coolant water in the plate flow channels and in the upper and lower plenums is entirely lost and the flow channels contain only air. A small air flow (38 CFH) is established up the channels from density differences in the axial direction. However, the primary heat sink for the blanket module is the liquid in the flooded cavity space and thermal conduction is the primary mode of heat transfer.

3.3 A boil-down case where one-half of the inventory of coolant water in the plate coolant channels and the water in the upper plenum is suddenly lost and the deposited power then gradually boils off the remaining water in the channels. 


\section{Analysis Results}

Results for the wet-channel and dry-channel accident scenarios are shown in Figs. 4-1 and 4-2 where the maximum aluminum temperature is plotted during the course of the accident. The dry channel and flooded cavity conditions begin 600 seconds after the loss of beam power. Figure 4-1 shows the resulting metal temperatures for three different assumptions. The lowest metal temperatures are obtained assuming that the channel remains full of water with no coolant flow (wet-channel case). In this case, even though the water does not flow, any water lost in the heated section of the channel through evaporation is replenished by water from the upper plenum and the channel cannot dry out. The highest metal temperatures in Fig. 4-1 are obtained assuming that the channel completely dries out and that the flooded cavity is in laminar flow. In this case we apply a heat transfer coefficient of $100 \mathrm{~W} / \mathrm{m}^{2}-\mathrm{C}$ at the cavity wall. Intermediate metal temperatures are obtained assuming a dry channel and laminar flow in the flooded cavity but with an increase in the surface metal heat transfer coefficient from the laminar flow value of $100 \mathrm{~W} / \mathrm{m}^{2}-\mathrm{C}$ to a boiling value of $10,000 \mathrm{~W} / \mathrm{m}^{2}-\mathrm{C}$ when the outer surface reaches the local saturation temperature.

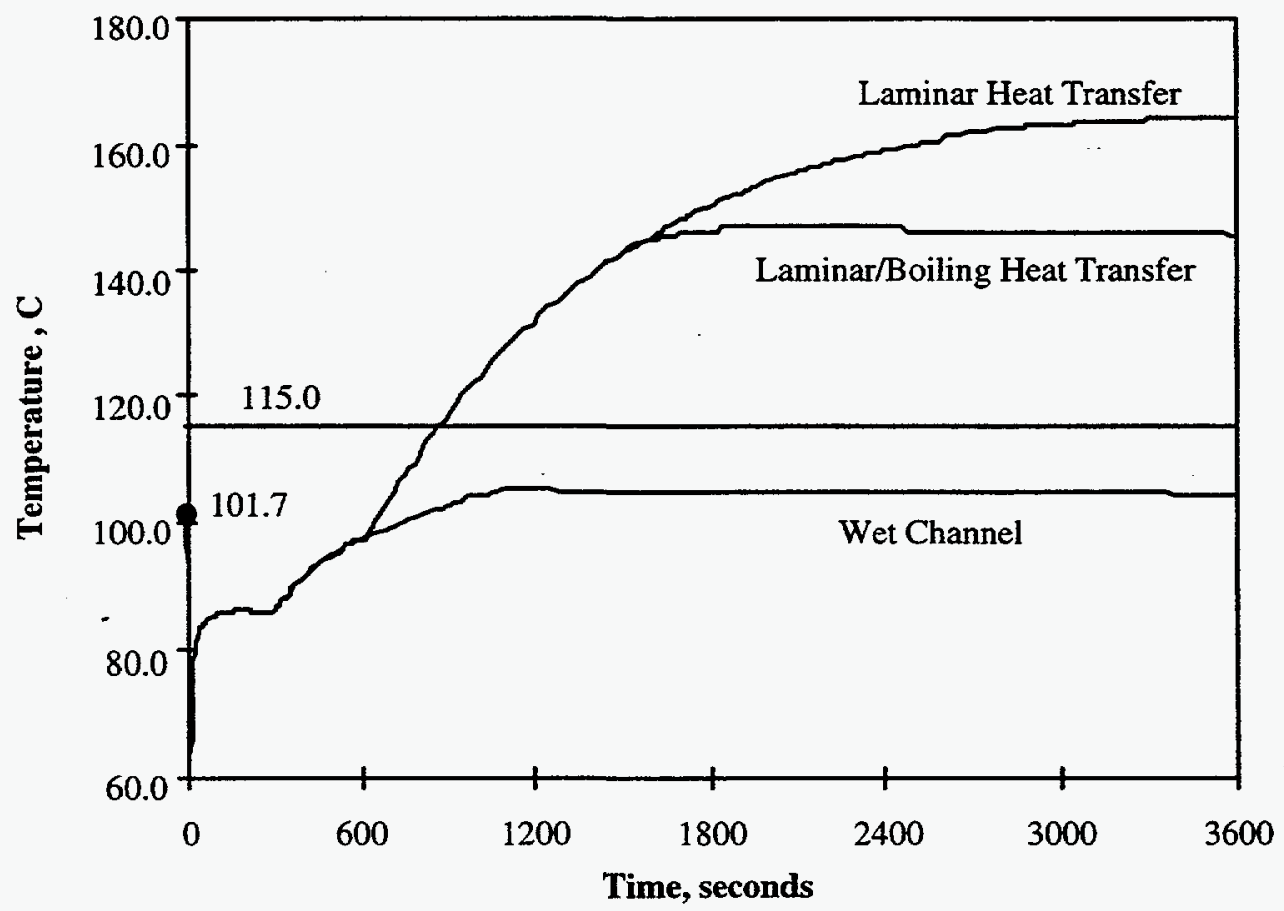

Figure 4-1 Maximum aluminum temperature during dry channel accident scenario.

Figure 4-2 shows the results of long term calculations of the maximum metal temperature assuming laminar flow on the cavity surface with the adjustment to the higher heat transfer coefficient for boiling conditions. Since it was not computationally reasonable to run such a long transient, a series of steady state runs were made at the indicated points on the curve. At each point, the plate power was set to the appropriate decay value and a steady-state calculation performed. The results show that the maximum aluminum temperature remains above $115 \mathrm{C}$ for about 100 hours and 
decreases asymptotically toward the $100 \mathrm{C}$ temperature assumed for the cavity coolant as the deposited power decays. A maximum aluminum temperature of $146 \mathrm{C}$ is reached about one half hour into the accident. Figure 4-3 shows a three-dimensional plot of surface temperatures on the plate at 3600 seconds after the start of the accident ( 3000 seconds after the dry channel flow conditions are established). As shown in the figure, a relatively large region of the plate has reached temperatures between $140 \mathrm{C}$ and $150 \mathrm{C}$. A cut-away view of the lower section of the mesh showing interior metal temperatures is presented in Fig. 4-4.

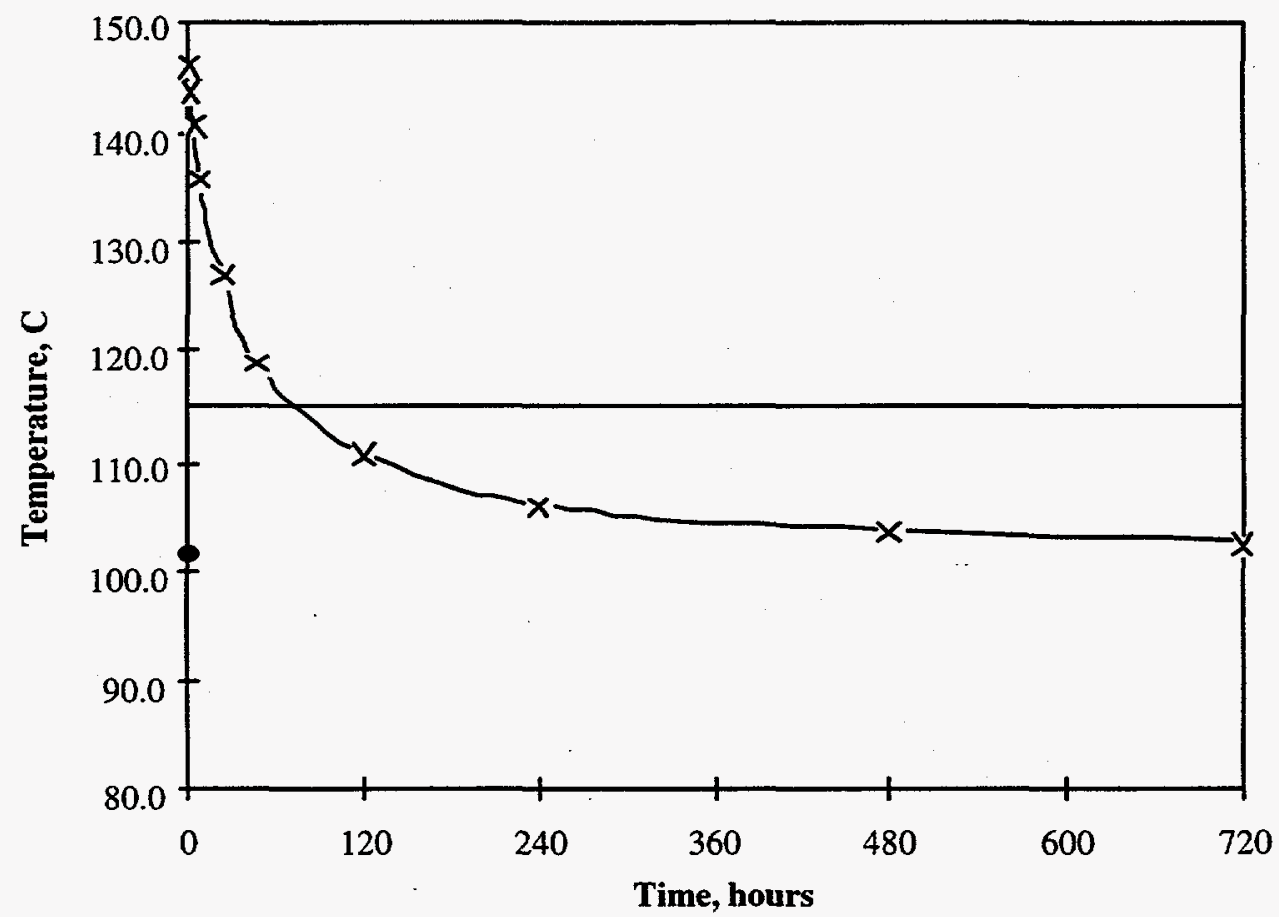

Figure 4-2 Maximum aluminum temperatures for internally dry channel scenario.

Figure 4-5 shows the power decay curve starting 600 seconds following the beam trip. There are approximately $1.4 \mathrm{~kg}$ of water in the 12 half flow channels surrounding each plate. Assuming that the deposited power is converted into latent heat of vaporization for the water, an average deposited power of $0.3 \mathrm{~kW}$ translates into a water boil-off rate of about $8 \mathrm{~g} / \mathrm{min}$. At this rate it will take on the order of 3 hours to boil the channels to dryness. Since some of the deposited power is absorbed by the metal and the average power over 3 hours is less than $0.3 \mathrm{~kW}$ the actual boil down time will be greater than 3 hours.

For these preliminary safety analyses, we did not try to boil off the water from a full plate module which would have required excessive computer time. However, as outlined above, a partial boil-down calculation was made starting with the coolant channels approximately half full of water. Figure 4-6 shows the mass of water in the coolant channels during the 30 minute boil-down calculation. Initially the water mass decreases at a rate close to the predicted $8 \mathrm{~g} / \mathrm{min}$. The boil-off rate slowly decreases to about 6 $\mathrm{g} / \mathrm{min}$ near the end of the calculation as the deposited power also decreases. Figure 47 shows the maximum aluminum temperature during the boil-down transient. 

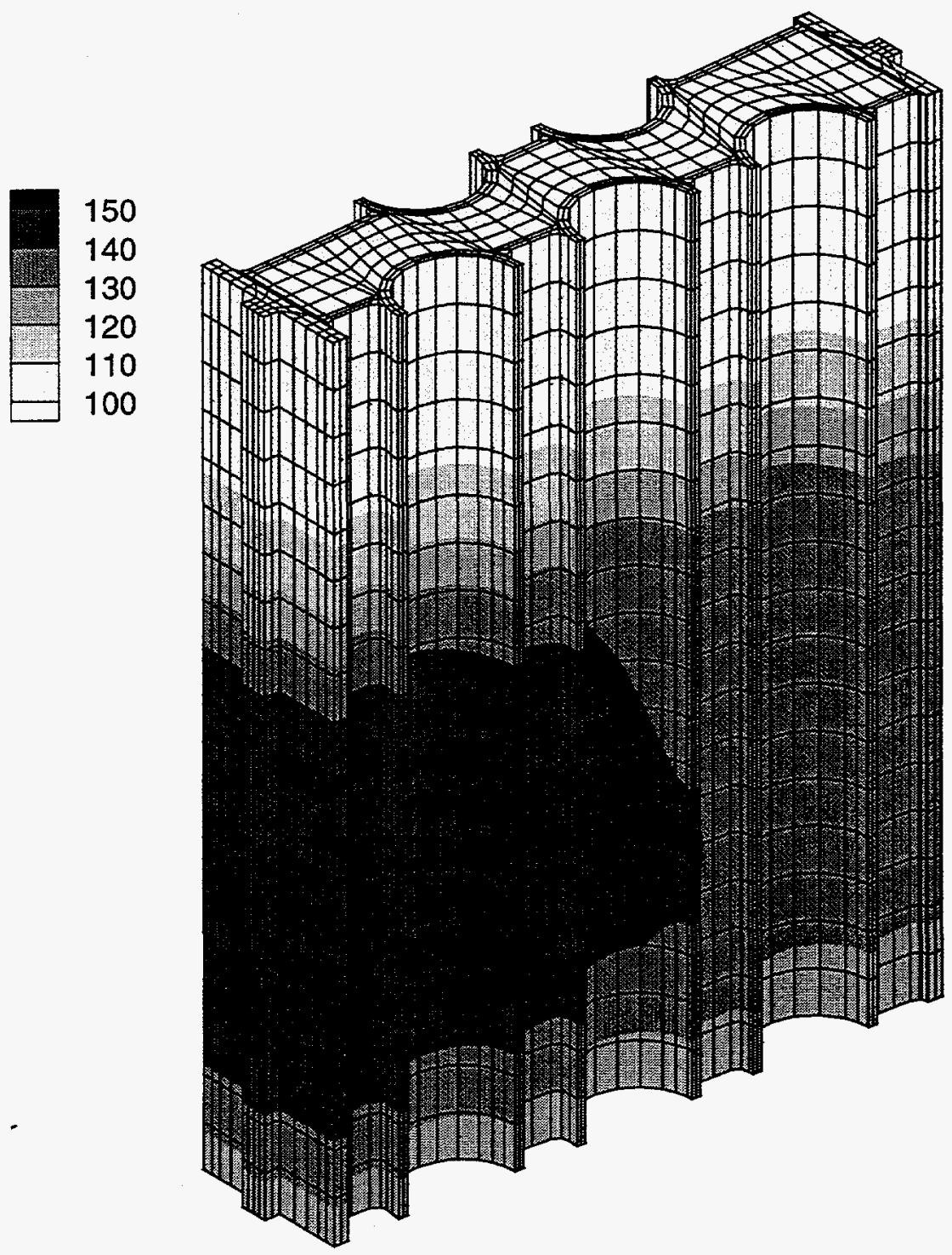

Figure 4-3 Plate surface temperatures at 3600 seconds with internally dry flow channels. 


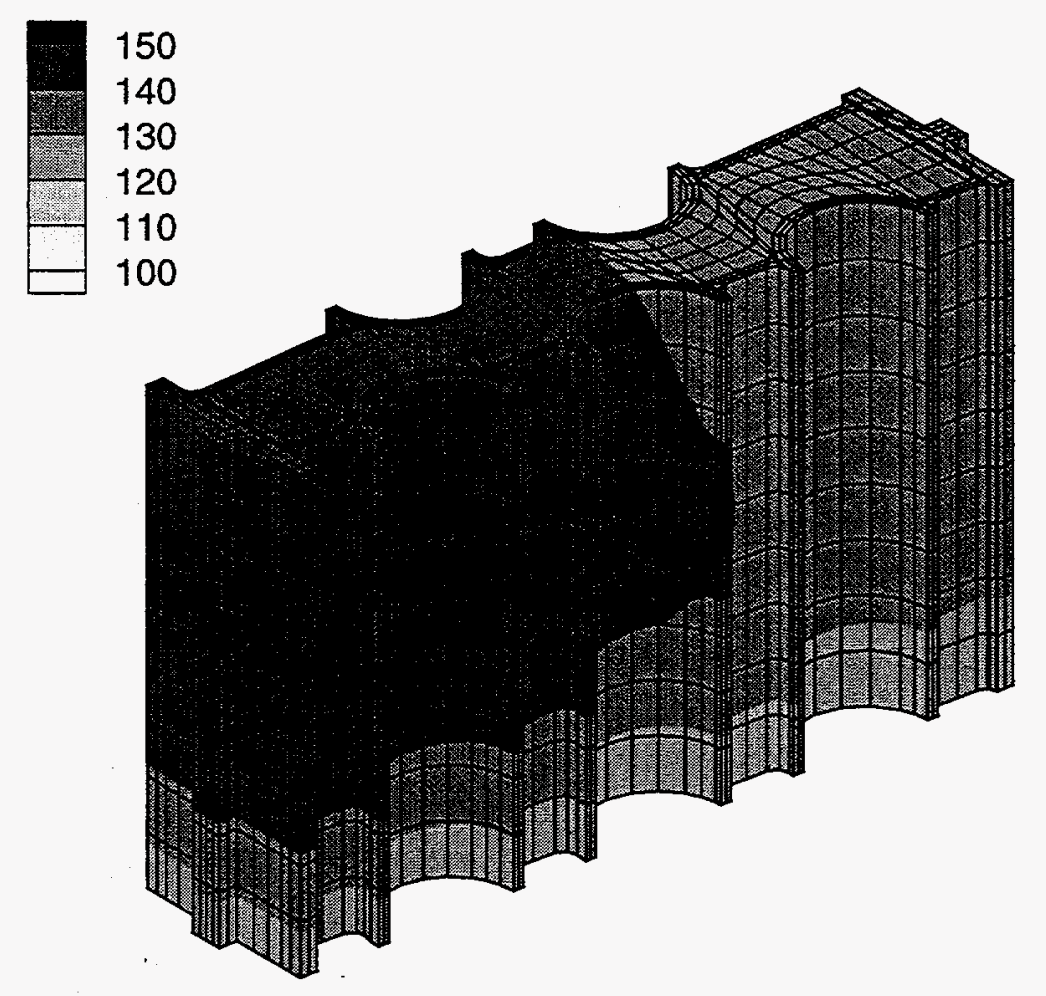

Figure 4-4 Cut-away view of plate temperatures at 3600 seconds with internally dry flow channels. 


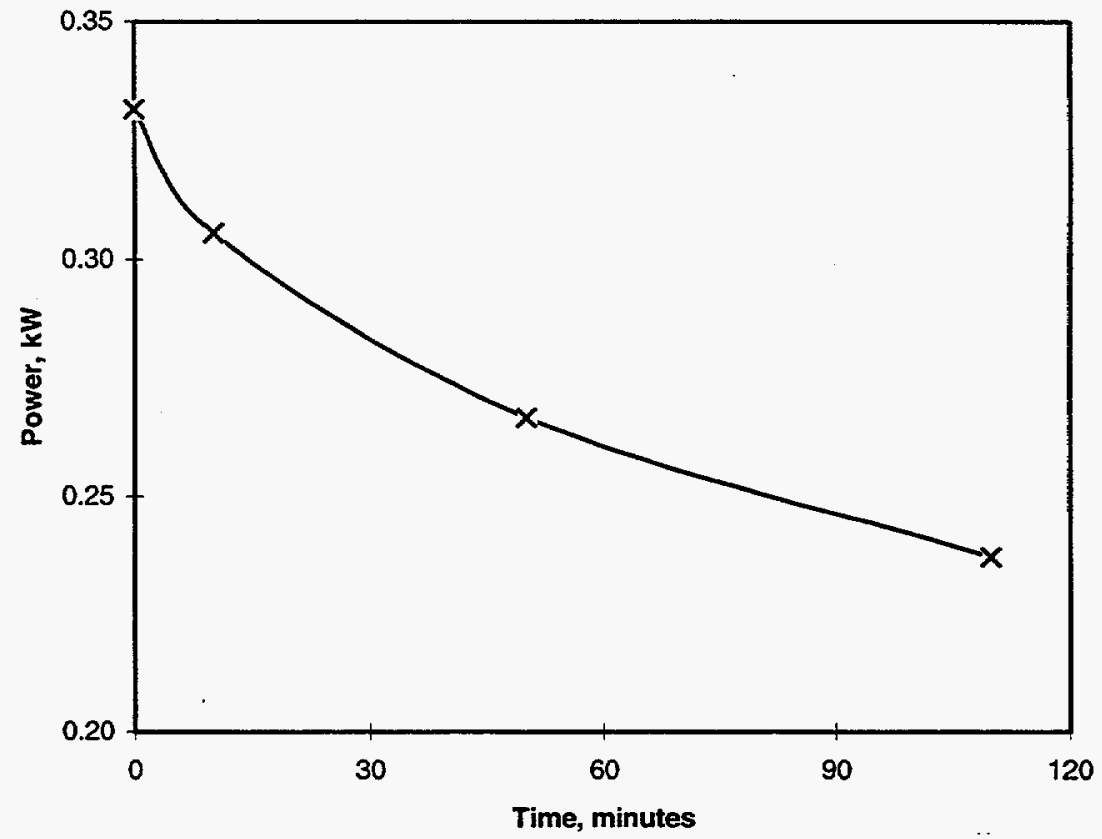

Figure 4-5 Deposited power in Row 1 Blanket plate starting 600 seconds after beam trip.

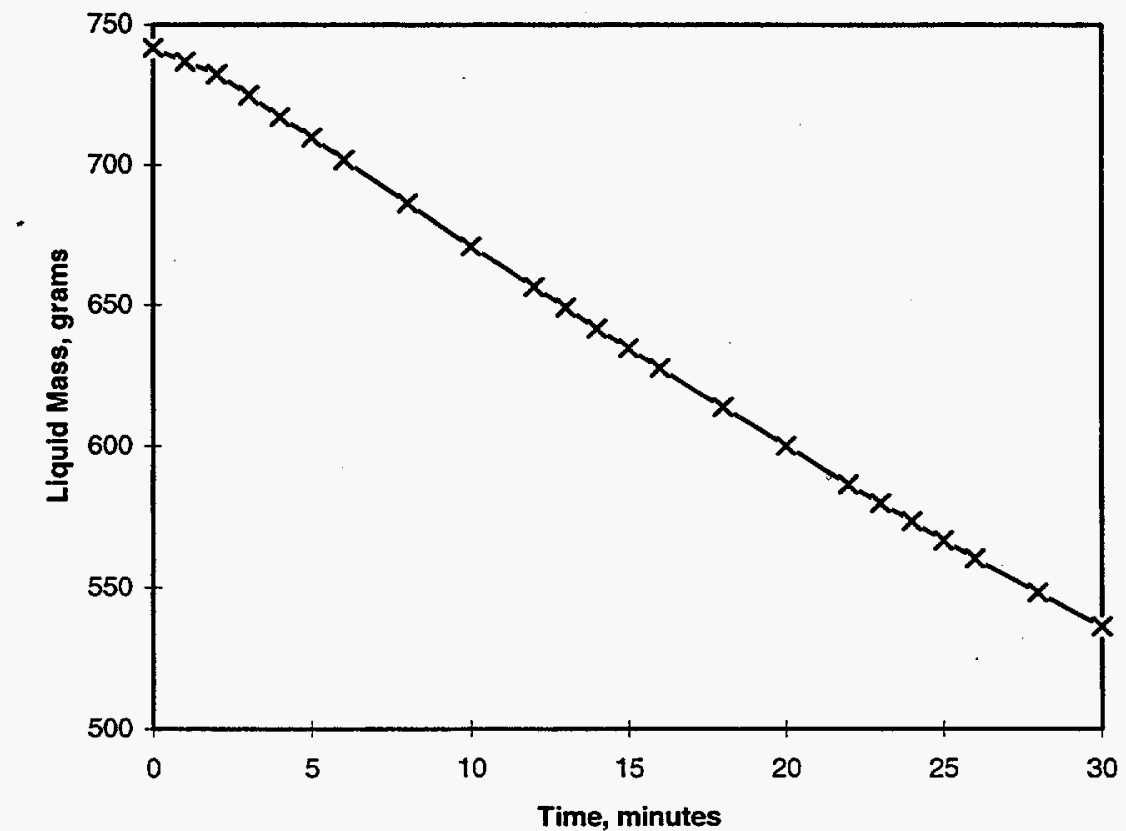

Figure 4-6 Liquid mass in Row 1 Blanket plate cooling channels during boiling. 


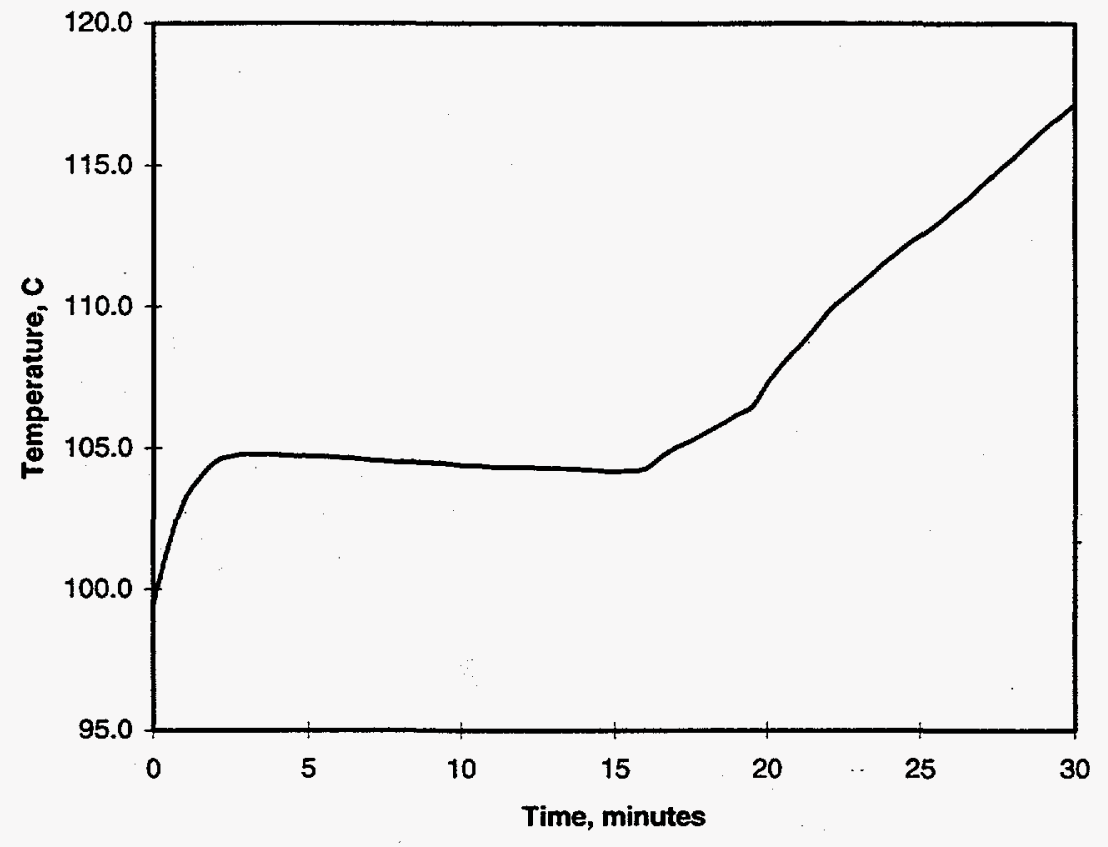

Figure 4-7 Maximum aluminum temperature in plate during boiling.

Starting with a half empty channel after about 15 minutes of boil-off we are beginning to expose the metal where deposited power densities are greatest. As more of the surface where deposited power is higher dries out the metal temperature begins to increase. Figure 4-8 shows surface temperatures on the plate module 30 minutes into the boildown transient. This preliminary calculation indicates that it would take at least 30 minutes for the metal temperature to reach $117 \mathrm{C}$ under these severe accident conditions. Starting with a coolant channel full of water would significantly increase the time required for metal heat-up. 


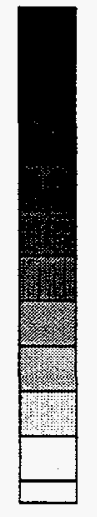

120
118
116
114
112
110
108
106
104
102
100

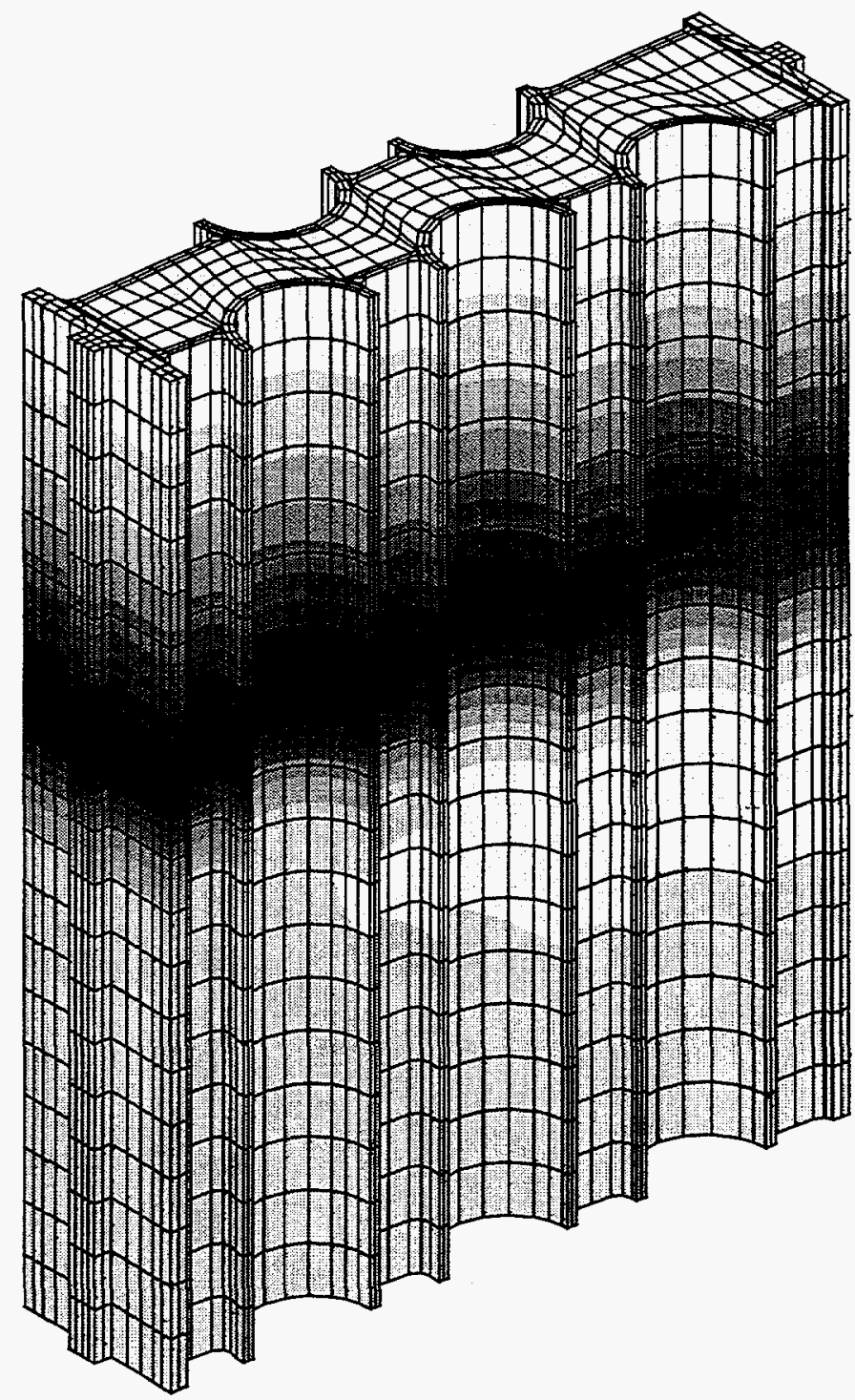

Figure 4-8 Temperature profile at 30 minutes.

Figures 4-9 and 4-10 show void fraction profiles in flow channels 1 and 8 , respectively at times of $0,10,20$ and 30 minutes into the boil-down. The initial void profile imposed on the fluid is very sharp with the top 9 cells of the channel completely voided and void fractions of less than 0.1 in the lower 10 cells. As boiling starts, this profile quickly transitions to one with significant void fractions in the lower part of the channels and complete voiding in fewer of the top cells. This general profile persists during the boildown while the number of completely void cells in the top region increases. Similar void profiles are present in the other flow channels with fluid boiling taking place in cells that have void fractions between zero and one. We note that FLOWTRAN-TF has some difficulty resolving the interface between partially and fully voided cells where the calculated void profile is not smooth. The void profile in this region is not physical and 
work is in progress to modify the two phase calculations to obtain a smoother void profile.

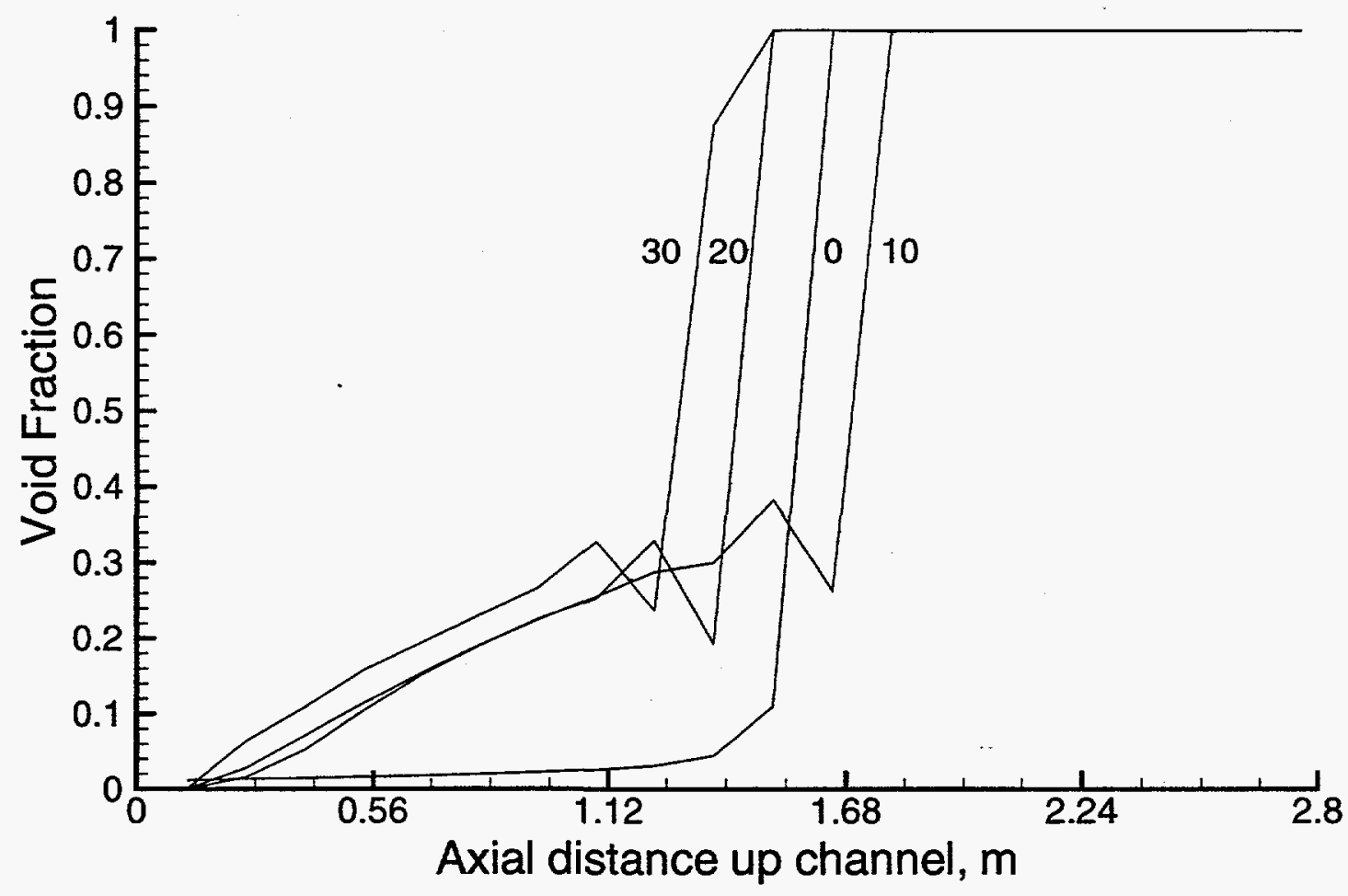

Figure 4-9 Void fraction in flow channel 1 during the boil-down transient.

For the case where a portion of the inventory is lost, the plate-type module was successful in boiling down the remaining water. At these deposited power levels the boil-down rate is very slow $(<8 \mathrm{~g} / \mathrm{min})$ and the time required to reach complete dryness becomes significant. Even under the extreme conditions of starting with a completely dry module (assuming the cavity vessel remains flooded and allowing boiling heat transfer on the outer surface), the aluminum temperature remains below the safety limit of $150 \mathrm{C}$. Material limits for the plate-type structures are tentatively set by the Materials Working Group to: (1) $115 \mathrm{C}$ for steady-state normal operation or indefinite times of exposure; and (2) $150 \mathrm{C}$ for exposures less than 10,000 hours. Therefore, a significant safety margin has been demonstrated for the reference 1 plate type design. 


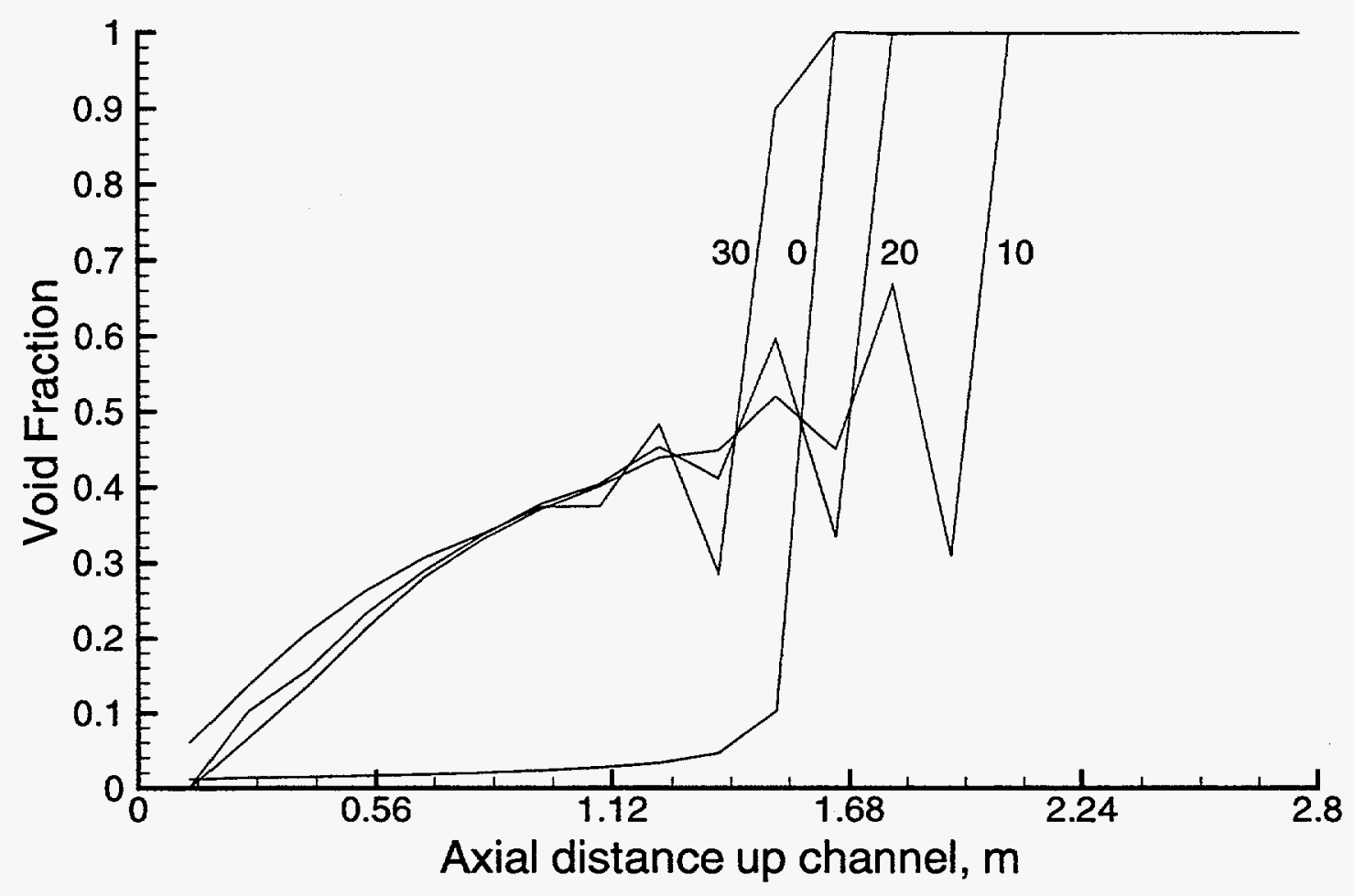

Figure 4-10 Void fraction in flow channel 8 during the boil-down transient.

\section{Decoupler Design Improvement Impact}

In the original reference 1 plate-type design of a lateral Row-1 module unit, the decoupler is attached to the Row-1 component such that coolant flow within the decoupler is in direct contact with the Row-1 face facing toward the target ladders. The results discussed earlier are based on that design. To improve the lateral conduction capability of the lateral and downstream module units, the decouplers were redesigned. Now, the faces of each Row-1 component, facing toward the target ladders, are in direct contact with the cavity vessel space. This allows direct heat transfer between those Row-1 faces and the cavity vessel under flooded cavity conditions.

As demonstrated below, the modified plate-type blanket design is very robust from a thermal perspective. The main feature of the plate-type design is its continuous heat structure at the bin level with discrete one-dimensional flow channels (of simple well known shapes) dispersed throughout the heat structure. For the highest powered modules (i.e., front/back lateral and downstream Row-1/decoupler modules) the horizontal conduction path lengths are kept to a minimum by allowing each plate component to be in direct contact with neighboring cavity vessel spaces on both its left and right faces.

Results presented below (and further discussed in Ref. 9) indicate that the modified plate-type design modules can by heat conduction alone transfer all of their decay heat to neighboring flooded cavity spaces (typically, small rectangular gaps on the order of 
one to one and a half inches wide). An evaluation model (EM) was developed based on several conservative assumptions to demonstrate the robust capability of the cavity flood system. This EM consists of the three-dimensional finite element conduction model of a section of a plate-type component (as described earlier within this report) that is driven by conservative boundary conditions. Basically, the conduction model within FLOWTRAN-TF is used where surface boundary conditions normally supplied through the conjugate heat transfer calculations is turned off and externally specified boundary conditions are provided. A summary of this EM and its key results are discussed below.

To help establish a scenario where a cavity flooded condition would be necessary, we shall look at a loss-of-flow accident (LOFA) with only a beam shutdown and no other mitigative actions are taken until the system pressure increases to the point of blanket system rupture. At this point a loss-of-çoolant accident (LOCA) is initiated and the cavity flood system is actuated. The slowest fill time corresponds to cases where an external break occurs and the only water entering the cavity vessel is due to gravity flow from the cavity pool.

As provided in Ref. 10, for LOFAs flywheel inertia extends the period of forced convective flow out beyond 100 seconds after beam shutdown. As shown in Ref. 10, between 100 and 2000 seconds the primary coolant system transitions into natural circulation (in a mixed convection mode). Beyond 2000 seconds, single-phase natural circulation persists until saturation conditions are reached approximately 200 hours later (see Ref. 10). However, in the EM it will be conservatively assumed at 100 seconds that successful transition to natural circulation is not achieved and that a external break LOCA along with complete loss of liquid coolant inventory (i.e., dryout conditions) results in one or more of the module units.

To estimate the time required for the cavity flood system to cover all key blanket components, a standalone TRAC model of the cavity pool and cavity vessel was used. A more detailed discussion of this TRAC model is provided in Section 6 of Ref. 11. Figure 5-1 shows the TRAC component layout for this standalone model. Figure 5-2 illustrates the relative elevations of various key cavity vessel components. During the TRAC simulation the valves located in components $840,842,850$, and 852 remained closed. Once the LOCA occurs, the valve located in component 828 was opened allowing the cavity vessel space to be vented to atmospheric conditions. Upon cavity flood actuation, the valve at component 821 was opened allowing gravity flow to occur from the flood pool over into the cavity vessel. Eventually, gravity flow diminishes to zero as the liquid levels between the cavity vessel space and the flood pool equilibrate.

As shown in Fig. 5-3, upon actuation of the cavity flood system all modules are covered with subcooled water in less than 100 seconds and by 800 seconds the tops of the fixed headers are covered. The results shown in Fig. 5-3 were computed base on the TRAC model discussed above.

For conservatism the component with the highest power density is considered (i.e., the downstream Row-1 component). A plan view of the model's mesh and boundary locations are provided in Fig. 5-4. Bounding fluid heat transfer conditions along the surfaces of the plate in contact with the cavity space are set based on the following set of assumptions. 


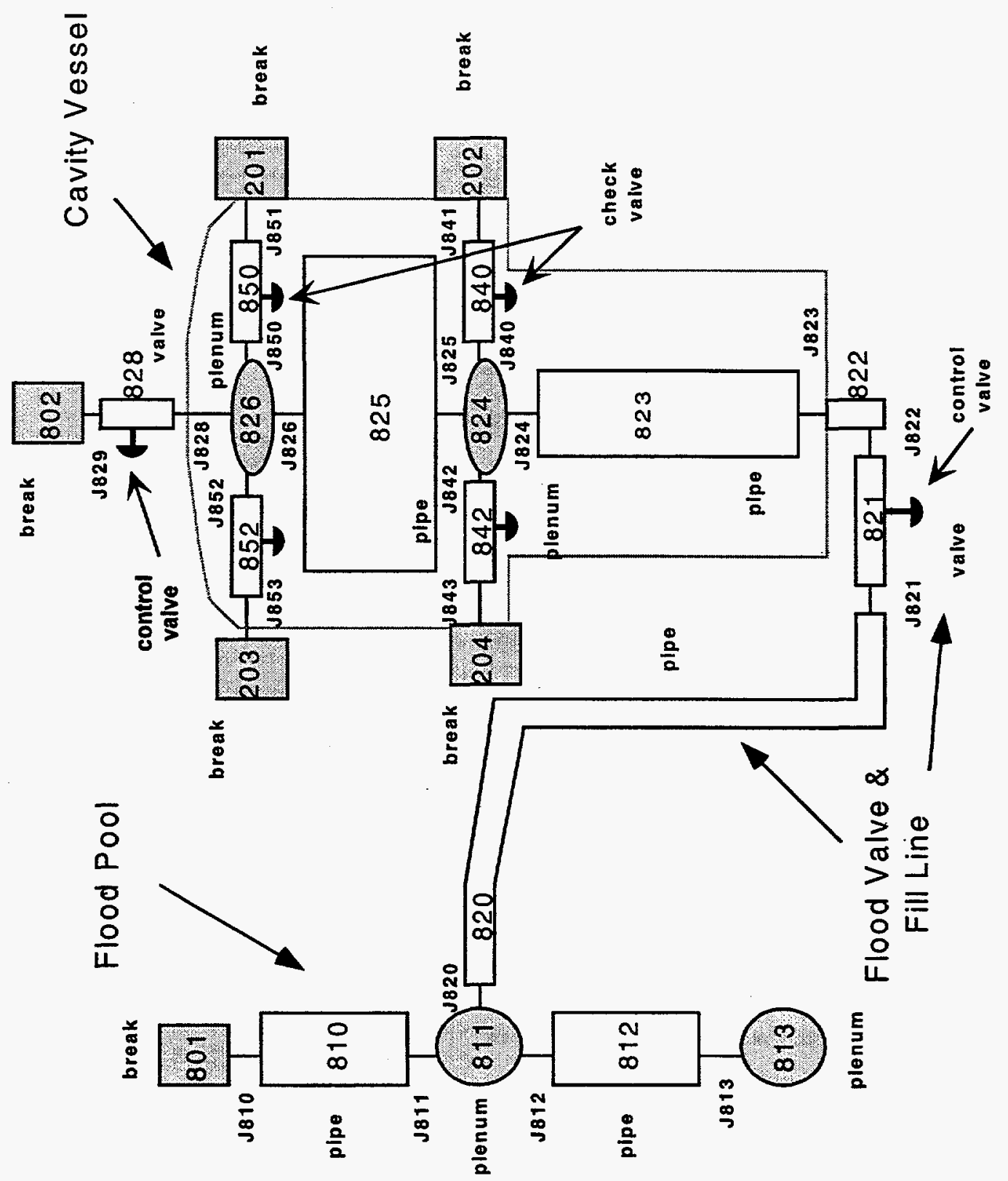

Figure 5-1 TRAC component layout for the cavity vessel and cavity flood system. 


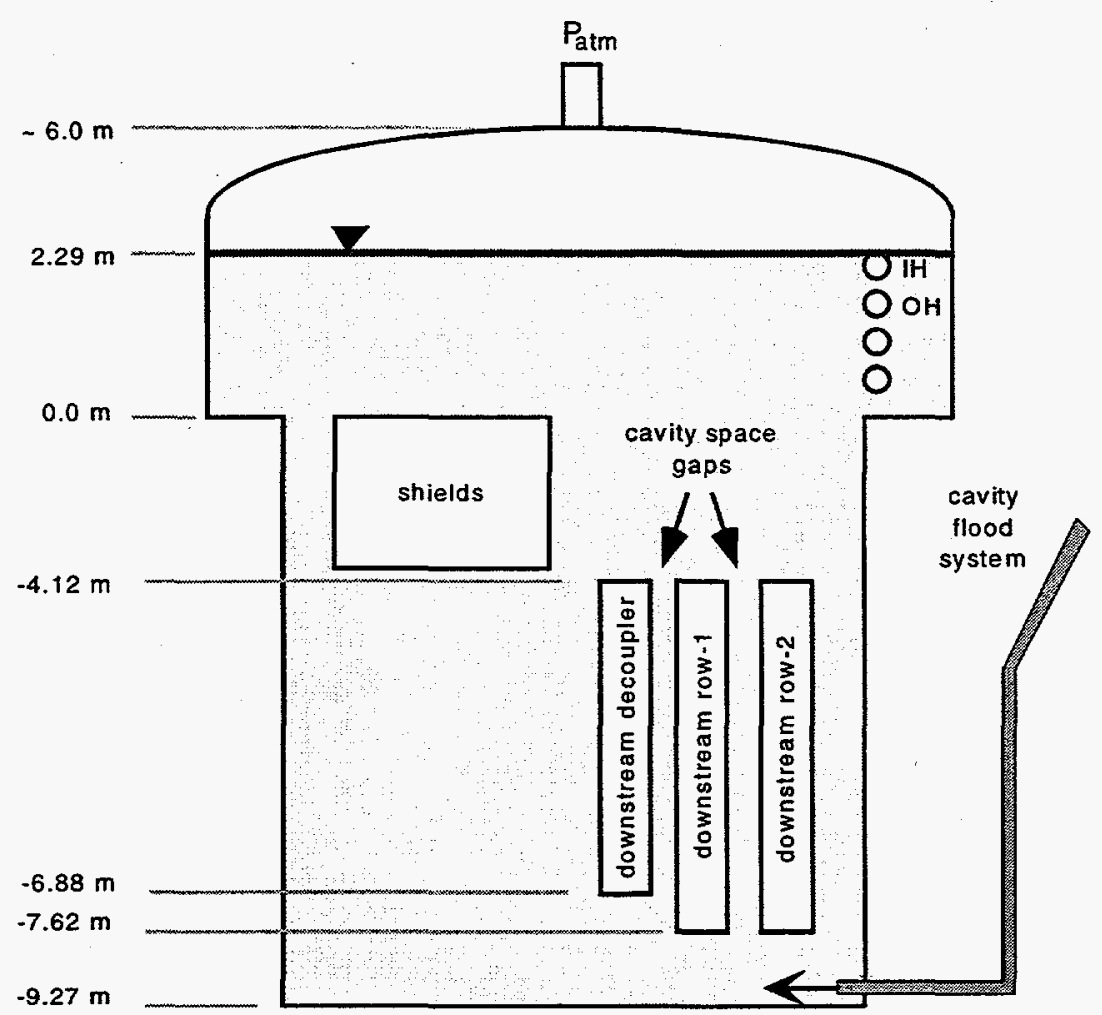

Figure 5-2 Vertical cross-sectional view of Target/Blanket vessel highlighting the elevation of key cavity vessel components.

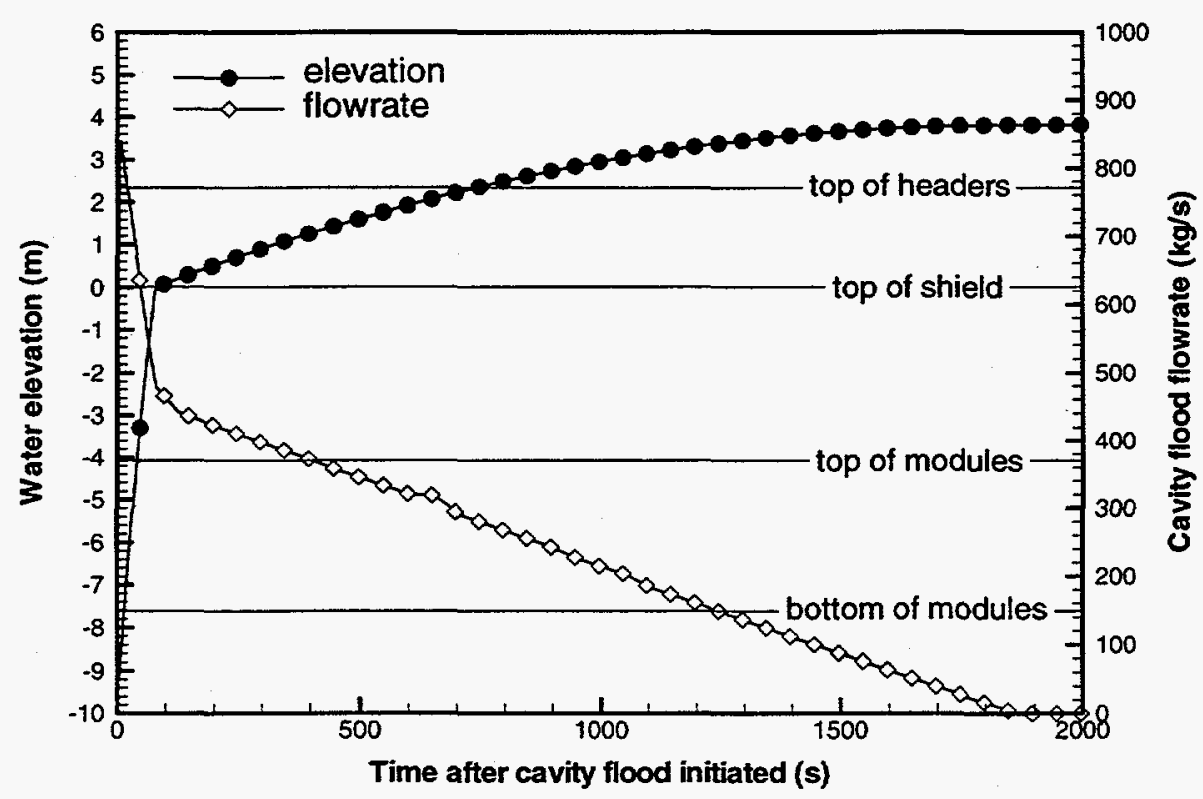

Figure 5-3 Timing associated with covering certain key cavity vessel components once a cavity flood actuation has been initiated. 


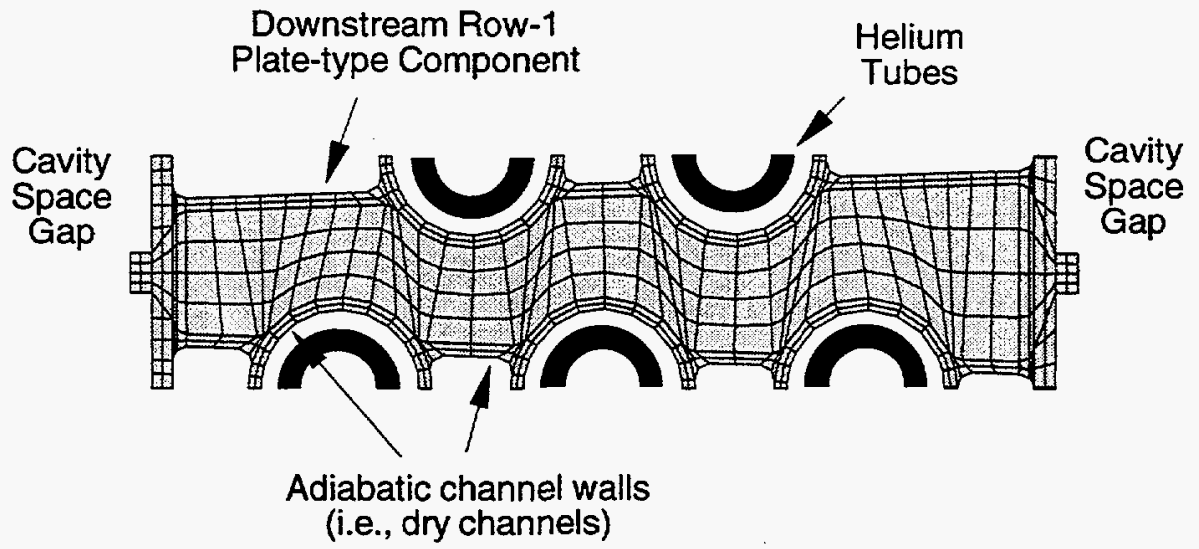

Figure 5-4 Plan view of downstream Row-1 plate-type component highlighting thermal boundary conditions used.

The hydrostatic pressure profile within the cavity space is computed based on the maximum level of water achievable. Currently, the flood pool is designed to cover the tops of the blanket headers. Atmospheric pressure is assumed to have been achieved within the air space above the liquid surface. This maximizes the saturation temperature and extends the region where low single-phase heat transfer is present. The higher the saturation temperature the higher the bulk fluid temperature within the cavity spaces and the longer single-phase heat transfer exists.

The mixed convection heat transfer coefficient within the cavity spaces (i.e., gaps) is limited to the laminar value for the largest expected gap widths of one inch. Under laminar conditions the Nusselt number becomes:

$$
N u_{L}=5.38
$$

which translates into liquid film coefficients $\left(\mathrm{W} / \mathrm{m}^{2}-\mathrm{C}\right)$ for the rectangular gaps of:

$$
h_{L}=\left\{\begin{array}{cc}
144.8 & \text { for half } \text { - inch gaps } \\
72.4 & \text { for one inch gaps }
\end{array}\right\}
$$

Under heated upflow conditions and expected within these rectangular gaps mixed convection heat transfer will result. The actual single-phase heat transfer coefficients will be larger than their laminar values as indicated in Ref. 12 [see page 15.22].

The onset of subcooled nucleate boiling (ONB) is delayed until a value of $15 \mathrm{C}$ wall superheat has been reached. It is anticipated that ONB will occur prior to this value. Conservatively, the boiling heat transfer coefficient within these gaps is set to the pool boiling value corresponding to a wall superheat of $10 \mathrm{C}$. From Ref. 13 pool boiling heat transfer coefficients $\left(\mathrm{W} / \mathrm{m}^{2}-\mathrm{C}\right)$ are approximately: 


$$
h_{P B}=\left\{\begin{array}{ll}
2000 & \text { for } 10 \mathrm{C} \text { wall superheat } \\
5000 & \text { for } 15 \mathrm{C} \text { wall superheat }
\end{array}\right\}
$$

Initial metal temperatures are set to $100 \mathrm{C}$. Actual conditions should correspond to 50 $60 \mathrm{C}$, however, the final results are reasonably insensitive to this value. Adiabatic boundary conditions are applied at the top and bottom of the plate component thermally separating it from neighboring solid structures (i.e., potential heat sinks).

Also, under the assumed complete dryout conditions it is further assumed that adiabatic boundaries exist between the plate and the fluid within the discrete flow channels.

Results of maximum aluminum/lead metal temperature based on the above EM are shown in Fig. 5-5. As illustrated in Fig. 5-5 for early times, the maximum metal temperature exceeds the steady-state design criteria of $115 \mathrm{C}$, but then drops below this limit beyond approximately 80 hours. At no time during this event sequence does the maximum metal temperature exceed its $10 \mathrm{k}$ hour exposure design criteria of $150 \mathrm{C}$.

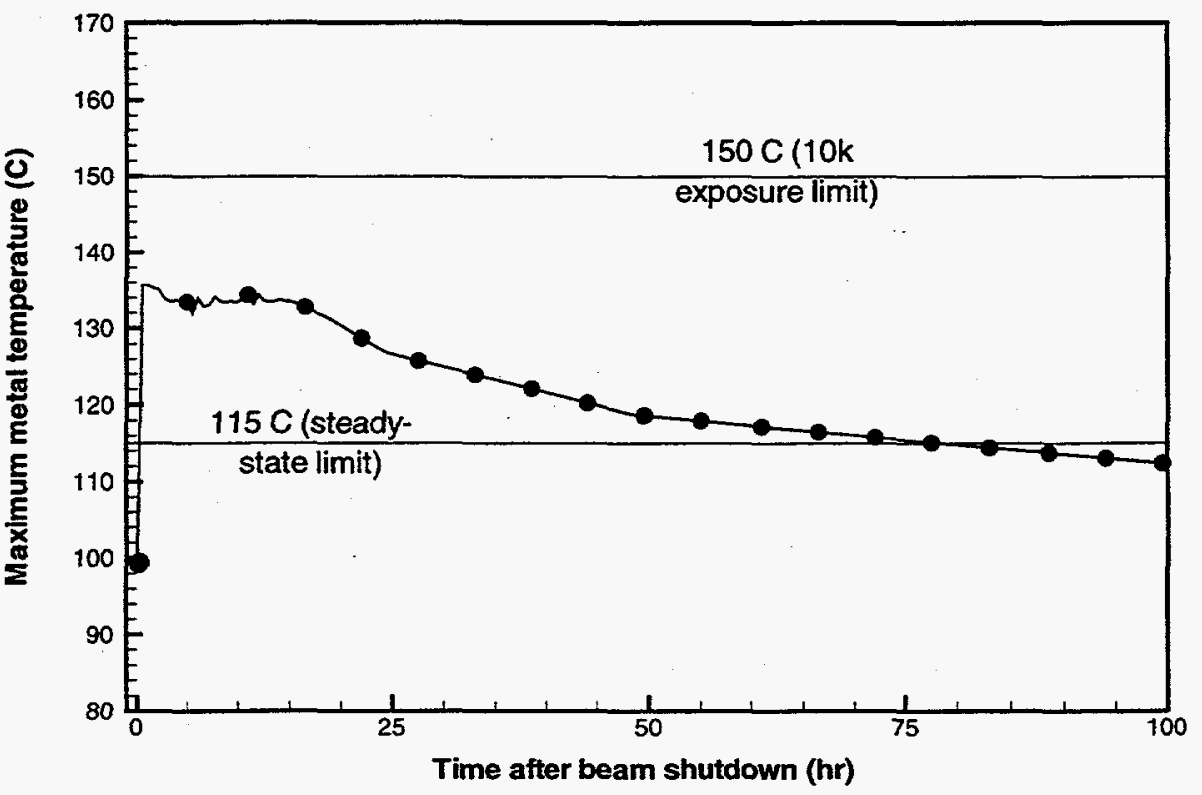

Figure 5-5 Downstream Row-1 plate-type maximum metal temperature response to channel dryout conditions initiated at 100 seconds after beam shutdown.

In this analysis, credit is taken for the cavity flood system and a beam shutdown. It is assumed that the cavity flood system successfully floods the cavity vessel within stated timing and dumps all decay heat received. For this particular analysis the cavity flood system becomes the only ultimate heat sink available. To ensure that the heat transfer rates predicted were achievable, a separate study was performed (see Ref. 14) to determine the maximum amount of power that can be transferred from the bin wall over to the cavity space without experiencing a counter-current-flow limitation (CCFL) within the flow gaps. The current spacing (i.e., one inch maximum and one half inch minimum) between neighboring blanket modules can accommodate all expected power loads without a CCFL phenomenon occurring. No credit is taken for the various conduction paths available to the surrounding building structures and ground. No credit is taken for 
any natural circulation patterns that may exists within the primary HR loop or the physical time required for inventory leakage or boil-off.

\section{References}

1. Aleman, S. E., G. P. Flach, L. L. Hamm, S. Y. Lee and F. G. Smith, III, FLOWTRAN-TF Software Design, WSRC-TR-92-532, February, 1993.

2. L. L. Hamm, S. Y. Lee, M. A. Shadday, and F. G. Smith, III, "APT Blanket Detailed Bin Model Based on Initial Plate-Type Design - 3D FLOWTRAN-TF Model," Westinghouse Savannah River Company, WSRC-TR-98-0055 (July 1998).

3. L. L. Hamm, S. Y. Lee, M. A. Shadday, and F. G. Smith, III, "FLOWTRAN-TF Code Modifications made for APT Blanket Safety Analyses," Westinghouse Savannah River Company, WSRC-TR-98-0056 (July 1998).

4. L. L. Hamm and M. A. Shadday, "APT Blanket Safety Analysis: Preliminary Hot Subchannel Model Results," Westinghouse Savannah River Company, Section memorandum number SRT-EMS-97-0024, April 9, 1997.

5. L. L. Hamm and M. A. Shadday, "APT Blanket Safety Analysis: Preliminary Internally Dry Flooded Cavity Results," Westinghouse Savannah River Company, Section memorandum number SRT-EMS-97-0030, May 2, 1997.

6. L. L. Hamm, S. Y. Lee, M. A. Shadday, and F. G. Smith, III, "Normal Operation (NO) of APT Blanket System and its Components Based on Initial Conceptual Design," Westinghouse Savannah River Company, WSRC-TR-98-0057 (July 1998).

7. L. L. Hamm and M. A. Shadday, "APT Blanket Safety Analysis: Preliminary Therma! Conduction Analysis of the B\&W Plate-Type Blanket Assembly (U)," Westinghouse Savannah River Company, Section memorandum number SRT-EMS-97-0039, June 2, 1997.

8. R. Kapernick, "Blanket Reference 1 Plate-Type Design for Lateral Row 1 Module", email memo from Los Alamos National Laboratory, Oct. 11, 1997.

9 L. L. Hamm, S. Y. Lee, M. A. Shadday, and F. G. Smith, III, "APT Blanket System Safety Analysis Methodology," Westinghouse Savannah River Company, WSRCTR-98-0052 (May 1998).

10 L. L. Hamm, S. Y. Lee, M. A. Shadday, and F. G. Smith, III, "APT Blanket System Loss-of-Flow Accident (LOFA) Analyses Based on Initial Conceptual Design - Case 2: with Beam Shutdown only," Westinghouse Savannah River Company, WSRC-TR98-0085 (July 1998).

11 L. L. Hamm, S. Y. Lee, M. A. Shadday, and F. G. Smith, III, "APT Blanket System Model Based on Initial Conceptual Design - Integrated 1-D TRAC System Model," Westinghouse Savannah River Company, WSRC-TR-98-0053 (July 1998).

12 S. Kakac, R. K. Shah, and W. Aung, Handbook of Single-Phase Convective Heat Transfer, John Wiley and Sons, 1987 (see page 15.22).

13 J. J. Ginoux, Two-Phase Flows and Heat Transfer - with Application to Nuclear Reactor Design Problems, McGraw-Hill Book Company, 1978 (see page 105).

14 S. Y. Lee and L. L. Hamm, "APT Blanket Safety Analysis: Counter Current Flow Limitation for Cavity Spaces," Westinghouse Savannah River Company, WSRC-TR98-0086 (July 1998). 